\title{
Immunoglobulin-bearing polymorphonuclear leucocytes in primary syphilis
}

\author{
J D BOS, F HAMERLINCK, AND R H CORMANE \\ From the Department of Dermatology, University of Amsterdam, Amsterdam, the Netherlands
}

SUMMARY Non-specific defence mechanisms are thought to be ineffective in eliminating Treponema pallidum after infection in the early stages, but studies aimed at the elucidation of this phenomenon are few.

In this study, the number of IgG-bearing polymorphonuclear leucocytes in patients with primary syphilis was increased; this is most probably a normal phenomenon of infection.

\section{Introduction}

The non-specific defence mechanisms are generally thought to be ineffective in eliminating Treponema pallidum after infection has been established. The combined efforts of polymorphonuclear leucocytes, mononuclear macrophages, and non-specific humoral factors are unable to neutralise the invading micro-organisms in the early stages of syphilis. Studies of polymorphonuclear leucocytes (PMNL) in syphilis are few. Histologically, PMNL are seen in the initial stage of primary syphilis, accumulating in the perilymphatic spaces, since later they are replaced by lymphocytes and plasma cells. ${ }^{1}$

Recently the elimination of treponemes by phagocytes after 7-8 hours of penicillin therapy could be demonstrated in early syphilitic lesions in humans using the electron microscope. ${ }^{2}$ In another study, syphilitic infection of rabbits was found to be significantly associated with increased metabolic activity of phagocytes as detected with the nitroblue tetrazolium test. ${ }^{3}$

In this study, the number of immunoglobulinbearing PMNL, isolated from peripheral blood, in a group of patients with primary syphilis was determined. Variations in the percentages of different Ig classes present on the membrane of circulating PMNL have previously been found in diseases such as allergic contact dermatitis and psoriasis. ${ }^{4}$

Address for reprints: $\mathrm{Dr}$ J D Bos, Academisch Ziekenhuis, Grimburgwal 10, 1012 GA Amsterdam, the Netherlands

Received for publication 4 December 1979

\section{Patients and methods}

STUDY POPULATION

The patients in this study were referred by the outpatient department of our hospital. A total of seven patients, all with primary syphilis, were studied. This group of patients was the same as that described in two previous papers on the percentages of $B$ and $T$ lymphoid cells in these patients. ${ }^{56}$ All the patients were male; five were untreated at the time of investigation whereas two were treated for less than one week (patients 9 and 12). The time interval from date of infection to time of investigation varied from 4-12 weeks.

\section{HEALTHY CONTROLS}

Ten healthy staff members served as controls for the quantitative determination of immunoglobulinbearing PMNL. All were male and of the same age group as the patients studied.

\section{ISOLATION OF POLYMORPHONUCLEAR LEUCOCYTES}

Separation of PMNL was carried out according to the method of Boyum ${ }^{7}$ with some minor modifications as described below. Fifty millilitres of peripheral blood were collected aseptically in Erlenmayer bats and defibrinated by shaking for 10 minutes with 50 glass beads; to this, $20 \mathrm{ml}$ of phosphate-buffered saline (PBS) was added. This suspension was layered on top of $40 \mathrm{ml}$ IsopaqueDextran* for 45 minutes; the red cells are clumped at

*Ten parts Isopaque solution mixed with 24 parts of $6 \%$ Dextran (Pharmacia, Uppsala, Sweden). 
the interface and sedimented at the bottom of the tube in $1 \times g$ gravity field.

The plasma layer was aspirated and washed once in PBS for five minutes at $200 \times g$. The centrifuged cells were resuspended in $80 \mathrm{ml}$ PBS and layered on Isopaque-Ficoll mixture. The latter suspension was centrifuged at $400 \times g$ for 20 minutes. The bottom of the tube contained the polymorphonuclear leucocytes.

\section{IN-VITRO IMMUNOFLUORESCENCE STUDIES OF} PMNL

After the isolated PMNL had been washed three times in PBS at $200 \times g$ for five minutes, the relative percentages of IgG-, IgA-, IgM-, IgD-, and IgEbearing PMNL were determined by immunofluorescence as described before. ${ }^{6}$

\section{PERIPHERAL BLOOD COUNTS}

Total peripheral leucocyte counts and their differentiation were estimated to relate percentage figures to the absolute numbers of PMNL.

\section{STATISTICAL METHOD}

The non-parametric Wilcoxon's test ${ }^{8}$ with the usual correction for ties, and the normal approximation to obtain the $P$ value, was used for statistical analysis of the numbers of immunoglobulin-bearing PMNL in patients with primary syphilis and in healthy controls.

\section{MATERIALS}

The materials used in this study were the same as those used in a previous study on lymphoid cells. ${ }^{6}$

\section{Results}

The results of the determination of percentages of immunoglobulin-bearing polymorphonuclear leucocytes for each of the five subclasses of immunoglobulins in patients and controls are given in the table. Absolute numbers of PMNL in the patients with primary syphilis were normal (mean $4 \cdot 41 \times 10^{9} / 1$; range $\left.1 \cdot 39-8 \cdot 38 \times 10^{9} / 1\right)$ and statistical analysis was performed on percentage figures. The exact values of standardised $\mathrm{W}$ and twosided tail probability, resulting from applying Wilcoxon's test to the obtained percentages, are also given in the table.

Although the number of patients studied was small, the percentage of IgG-bearing PMNL was significantly increased in the patients with primary syphilis $(P=0.0032)$. Furthermore, the number of IgE-bearing PMNL were significantly decreased in patients with primary syphilis $(P=0.0206)$ as were the number of IgD-bearing PMNL $(P=0 \cdot 0140)$.
TABLE Percentages of immunoglobulin-bearing polymorphonuclear leucocytes in seven patients and 10 controls

\begin{tabular}{|c|c|c|c|c|c|}
\hline & \multicolumn{5}{|c|}{ Immunoglobulin-bearing PMNL (\%) } \\
\hline & $\operatorname{Ig} G$ & $\operatorname{Ig} A$ & IgM & $\operatorname{IgD}$ & $I g E$ \\
\hline $\begin{array}{c}\text { Patient No } \\
5 \\
6 \\
7 \\
8 \\
9 \\
11 \\
12 \\
\text { Range } \\
\text { Median }\end{array}$ & $\begin{array}{c}5 \\
15 \\
3 \\
11 \\
11 \\
5 \\
4 \\
3-15 \\
5\end{array}$ & $\begin{array}{c}2 \\
5 \\
0 \\
4 \\
5 \\
0 \\
3 \\
0-5 \\
3\end{array}$ & $\begin{array}{c}10 \\
7 \\
4 \\
14 \\
9 \\
2 \\
8 \\
2-14 \\
8\end{array}$ & $\begin{array}{c}1 \\
5 \\
2 \\
2 \\
3 \\
0 \\
0 \\
0-5 \\
2\end{array}$ & $\begin{array}{c}1 \\
2 \\
1 \\
3 \\
3 \\
0 \\
0 \\
0-3 \\
1\end{array}$ \\
\hline $\begin{array}{c}\text { Control No } \\
1 \\
2 \\
3 \\
4 \\
5 \\
6 \\
7 \\
8 \\
9 \\
10 \\
\text { Range } \\
\text { Median }\end{array}$ & $\begin{array}{c}1.0 \\
1.5 \\
1.5 \\
1.5 \\
1.0 \\
2.4 \\
3.0 \\
6.0 \\
0.5 \\
0.5 \\
.5-6.0 \\
1.9\end{array}$ & $\begin{array}{c}2 \cdot 0 \\
5 \cdot 0 \\
3 \cdot 0 \\
0 \cdot 5 \\
1 \cdot 3 \\
3 \cdot 8 \\
2 \cdot 6 \\
7 \cdot 0 \\
0 \cdot 5 \\
0 \cdot 5 \\
0 \cdot 5-7 \cdot 0 \\
2 \cdot 6\end{array}$ & $\begin{array}{c}4 \cdot 0 \\
4 \cdot 0 \\
7 \cdot 5 \\
7 \cdot 3 \\
6 \cdot 0 \\
7 \cdot 8 \\
7 \cdot 5 \\
9 \cdot 0 \\
2 \cdot 0 \\
2 \cdot 5 \\
2 \cdot 0-9 \cdot 0 \\
5 \cdot 8\end{array}$ & $\begin{array}{c}2 \cdot 0 \\
7 \cdot 5 \\
6 \cdot 0 \\
3 \cdot 0 \\
5 \cdot 6 \\
6 \cdot 5 \\
9 \cdot 3 \\
7 \cdot 0 \\
2 \cdot 0 \\
2 \cdot 5 \\
2 \cdot 0-9 \cdot 3 \\
5 \cdot 1\end{array}$ & $\begin{array}{c}1 \cdot 0 \\
4 \cdot 0 \\
7 \cdot 0 \\
1 \cdot 5 \\
6 \cdot 3 \\
3 \cdot 0 \\
10 \cdot 2 \\
8 \cdot 0 \\
3 \cdot 0 \\
2 \cdot 5 \\
1 \cdot 0-10 \cdot 2 \\
4 \cdot 8\end{array}$ \\
\hline $\begin{array}{l}\text { Wilcoxon's } \\
\text { test } \\
\text { Probability }\end{array}$ & $\begin{array}{r}2.9930 \\
\text { y } 0.0032\end{array}$ & $\begin{array}{l}0.0983 \\
0.9608\end{array}$ & $\begin{array}{l}1 \cdot 1761 \\
0 \cdot 2597\end{array}$ & $\begin{array}{r}-2 \cdot 5070 \\
0 \cdot 0140\end{array}$ & $\begin{array}{r}-2 \cdot 3640 \\
0.0206\end{array}$ \\
\hline
\end{tabular}

\section{Discussion}

In this study, data are presented which suggest alterations in surface immunoglobulins of PMNL as a result of infection with $T$ pallidum. The increased number of IgG-bearing PMNL in some but not all patients with primary syphilis may indicate adherence of immune complexes consisting of treponemal antigens and antitreponemal IgG, these complexes being bound by way of $\mathrm{C} 3 \mathrm{~b}$ and $\mathrm{Fc}$ receptors to the membrane of circulating PMNL. 9 Phagocytosis and intracellular processing of treponemal constituents must have taken place since humoral responses were generally present in the patients studied.

Interpretation of the decreased number of IgDand IgE-bearing PMNL is difficult and its significance too low to allow conclusions to be drawn. Increased numbers of IgG-bearing PMNL do not seem to be disease-specific but seem to be the result of IgG-production as a humoral response to infection. In this study, no data on the ineffectiveness of non-specific defence mechanisms in syphilis are given but the results may indicate the normal processing of immune complexes in primary syphilis. Further studies to elucidate the origin of ineffective non-specific defence mechanisms in syphilis are needed. 


\section{References}

1. Treponematoses research: report of a WHO scientific group. Wld Health Org Techn Rep Ser 1970; 455:74-8.

2. Wecke J, Bartunek J, Stüttgen $G$. Treponema pallidum in early syphilitic lesions in humans during high-dosage penicillin therapy: an electron microscopical study. Arch Derm Res 1976;257:1-15.

3. Wicher V, Blakowski, S, Wicher $K$. Nitroblue tetrazolium test in experimental syphilis. Br J Vener Dis 1977;53:292-4.

4. Hunyadi J, Hamerlinck F, Cormane RH. Immunoglobulinand complement-bearing polymorphonuclear leucocytes in allergic contact dermatitis and psoriasis vulgaris. $\mathrm{Br} J$ Derm 1976;94:417-22.
5. Bos JD, Hamerlinck F, Cormane RH. T-lymphoid cells in primary syphilis. Br J Vener Dis 1980; 56: 74-6.

6. Bos JD, Hamerlinck F, Cormane RH. Immunoglobulinbearing lymphoid cells in primary syphilis; quantitative and elution studies. Br J Vener Dis 1980;56:69-73.

7. Böyum A. Separation of leukocytes from blood and bone marrow. Scand J Clin Lab Invest 1968;21, suppl 97: 1-106.

8. Siegel S. Nonparametric Statistics. New York: McGraw-Hill, 1956.

9. Valdimarsson H. Immunity and immunity deficiency. In: Hobart MJ, McConnell I, eds. The Immune System. 3rd ed. Oxford: Blackwell Scientific Publications, 1978;317-32. 